\title{
CAFFEINE-MEDIATED CHANGES OF SEX RATIO IN CHINESE HAMSTERS, CRICETULUS GRISEUS
}

\author{
P. S. WEATHERSBEE, R. L. AX AND J. R. LODGE \\ Department of Dairy Science, University of Illinois at Urbana-Champaign, \\ Illinois 61801, U.S.A.
}

(Received 2nd September 1974)

\begin{abstract}
Summary. Sixty 6- to 10-week-old male Chinese hamsters were assigned to two groups. In one, the animals were untreated and in the other, they were treated with $0.02 \mathrm{~g}$ caffeine $/ 100 \mathrm{ml}$ water orally for 60 days. The sex ratio of the resulting litters showed a significant $(P<0.025)$ skewing towards females $(61.4 \%)$ when compared to that of the controls $(49 \cdot 2 \%)$.
\end{abstract}

The mutagenic and teratogenic effects of caffeine and its derivatives have been the subject of reviews for animal cells treated in vivo (Peters, 1967; Mulvihill, 1973) and in vitro (Kuhlman, Fromme, Heege \& Ostertag, 1968). Though the exact mode of action has not been established, reports indicate the formation of both caffeine-bound complexes (Ts'o \& Lu, 1963) and smaller DNA replicating units (Lehmann, 1972) when caffeine is present. Binding in this manner reduces the activity of DNA polymerase (Wragg, Carr \& Ross, 1967) and possibly interferes (Kuhlman et al., 1968) with the repair of previously nicked or damaged strands, resulting in translocations, deletions and fragmentations of chromosomes as reported for bacteria (Grigg, 1968) and plants (Kihlman \& Levan, 1949).

Differential effects of caffeine on male- and female-derived cells have been noted in human lymphocyte cultures (Timson, 1970) and Drosophila (Mittler, Mittler \& Owens, 1967; Kuhlman et al., 1968). Previous results from this laboratory (unpublished) showed that continuous oral administration of caffeine $(0.02 \mathrm{~g} / 100 \mathrm{ml})$ to male and female Chinese hamsters caged together caused a significant shift in the sex ratio of the young in the resulting litters towards the female side. This study was undertaken as a further investigation of the phenomenon and to determine whether the effect was on the male or the female.

Chinese hamsters (Cricetulus griseus) originally purchased from Chickline, Vineland, New Jersey, were reared in our laboratory in breeding groups consisting of five females and four males, and the resulting offspring were utilized in this study. They were maintained in polystyrene cages $(24.0 \times 45.0 \times 14 \mathrm{~cm})$ at $22 \pm 3^{\circ} \mathrm{C}$ and were exposed to a 14 -hr light/10-hr dark photoperiod. Feed (Wayne Lab Blox, Allied Mills) was supplied without restriction.

A total of sixty 6 - to 10 -week-old male hamsters which had been previously earmarked were randomly assigned according to a $2 \times 3$ factorial design. Caffeine (1,3,7-trimethylxanthine: Nutritional Biochemicals Corporation) was sup- 
plied freely in the tap water $(0.02 \mathrm{~g} / 100 \mathrm{ml})$ to the treated males for a period of 60 days. After this initial period, males were maintained on treatment except during nightly periods of mating to randomly assigned untreated multiparous females. The young in the resulting litters were counted, their sex determined and they were examined at birth for abnormalities.

Table I summarizes the data from sixty-nine litters of Chinese hamsters sired by untreated or caffeine-treated males. A significant change in sex ratio was noted, the control and treated males producing respectively, $50.8 \%$ and $38.6 \%$ of phenotypically male offspring at birth $\left(\chi^{2}=5.7246 ; P<0.025\right)$. Analysis of variance showed no significant differences among treatment replicates. Whether this change in sex ratio was a direct effect of caffeine or one of its metabolites could not be determined from the results presented.

Table 1. Effect of continuous oral caffeine treatment of male Chinese hamsters on the sex ratio of their progeny

\begin{tabular}{cccccc}
\hline $\begin{array}{c}\text { Caffeine } \\
(\mathrm{g} / 100 \mathrm{ml})\end{array}$ & $\begin{array}{c}\text { No. of } \\
\text { litters }\end{array}$ & $\begin{array}{c}\text { Litter size } \\
(\text { Mean } \pm \text { S.D. })\end{array}$ & Males & Females & $\begin{array}{c}\% \\
\text { Males }\end{array}$ \\
\hline 0.00 (control) & 34 & $5.7+1.8$ N.S. & 99 & 96 & 50.8 \\
0.02 & 35 & $5.4+1.8$ N.S. & $73^{*}$ & $116^{*}$ & 38.6 \\
\hline
\end{tabular}

N.S. $=$ not significant by analysis of variance $(P>0.05)$.

* Significantly different from the sex ratio of control offspring by $\chi^{2}$ test $(P<0.025)$.

Since caffeine readily passes into human gonadal and fetal tissue at the same levels as those seen in the plasma before metabolism (Goldstein \& Warren, 1962), the effect might be due to a direct interaction with the DNA moiety (Kuhlman et al., 1968) or to inactivation of the enzyme phosphodiesterase (Butcher \& Sutherland, 1962) causing heightened intracellular levels of cyclic AMP. Intracellular levels of cyclic AMP and the rate of DNA synthesis have been shown to be inversely related (Abell \& Monahan, 1973). Increased levels of cyclic AMP have also been shown to cause a significant suppression or complete inhibition of mitosis in human lymphoid cells (Millis, Forrest \& Pious, 1972). Investigators using mouse testes in vitro (Slizynski, 1971) and in vivo (Adler \& Rohrborn, 1969) have observed chromosomal stickiness, clumping, rearrangements, and chromatin extrusion following administration of caffeine. In a recent study (R. L. Ax, unpublished observations), spermatogenesis in the rooster was completely suppressed after 30 days of treatment with caffeine $(0 \cdot 1 \%)$ mixed by weight into a standard ration. This effect was reversible, normal sperm production returning 3 weeks after the last treatment.

In the present study, there was no significant difference in litter size at birth between treated and untreated males. This suggests that spermatogenesis was not depressed enough to affect fertility, but that the production and/or maturation of Y-bearing spermatozoa may be selectively inhibited or altered. The explanation is strengthened by the fact that there was no change in the sex ratio of the nine litters of females treated with $0.02 \mathrm{~g}$ caffeine $/ 100 \mathrm{ml}$ and mated by untreated males $(53.4 \%$ males $)$. 
Early work (Andrew, 1959) with male Drosophila suggested that caffeine was more harmful at later stages of spermiogenesis than at the pre-meiotic stages. More recently, Mittler et al. (1967) have reported the appearance of XO males and $\mathrm{XXY}$ females in young following caffeine treatment of the parents and the question was raised whether $\mathrm{XO}$ males resulted from non-disjunction rather than chromosome breakage. The present study with Chinese hamsters and two other studies with Drosophila (Mittler et al., 1967; Kuhlman et al., 1968) are the only reports in the literature linking caffeine administration to an increased incidence of female offspring.

Work is in progress to characterize the physiological and genetic changes which occur in male Chinese hamsters and their offspring with caffeine treatment. It is regarded as of prime importance to determine where the effect on sex ratio occurs.

The authors wish to thank $\operatorname{Dr} A$. V. Nalbandov for his suggestions and criticisms during the preparation of the manuscript. The study was supported in part by the Illinois Agricultural Experiment Station.

\section{REFERENGES}

Abeli, C. W. \& Monahan, T. M. (1973) The role of adenosine $3^{\prime}, 5^{\prime}$-cyclic monophosphate in the regulation of mammalian cell division. F. Cell Biol. 59, 549-558.

AdLer, I. D. \& Rohrborn, G. (1969) Cytogenetic investigation of meiotic chromosomes of male mice after chronic caffeine treatment. Hum. Genet. 8, 81-85.

Andrew, L. E. (1959) The mutagenic activity of caffeine in Drosophila. Am. Nat. 93, 135-138.

Butcher, R. W. \& Sutherland, E. W. (1962) Adenosine 3',5'-phosphate in biological materials. I. Purification and properties of cyclic $3^{\prime}, 5^{\prime}$-nucleotide phosphodiesterase and use of this enzyme to characterize adenosine 3',5'-phosphate in human urine. f. biol. Chem. 237, 1244-1250.

Goldstein, A. \& WARREn, R. (1962) Passage of caffeine into human gonadal and fetal tissue. Biochem. Pharmac. 11, 166-168.

GrigG, G. W. (1968) Caffeine-death in Escherichia coli. Z. VererbLehre, 102, 316-335.

Kinlman, B. A. \& Levan, A. (1949) The cytological effects of caffeine. Hereditas, 35, 109-114.

Kuhlman, W., Fromme, H. G., Heege, E. M. \& Ostertag, W. (1968) The mutagenic action of caffeine in higher organisms. Cancer Res. 28, 2375-2389.

Lehman, A. R. (1972) Effect of caffeine on DNA synthesis in mammalian cells. 7. biophys. Cytol. 12, $1316-1325$.

Millis, A. J. T., Forrest, G. \& Prous, D. A. (1972) Cyclic AMP in cultured human lymphoid cells: relationship to mitosis. Biochem. biophys. Res. Commun. 49, 1645-1649.

Mrttreer, S., Mittler, J. E. \& Owens, S. L. (1967) Loss of chromosomes and nondisjunction induced by caffeine in Drosophila. Nature, Lond. 214, 424.

Mulvirill, J. V. (1973) Caffeine as teratogen and mutagen. Teratology, 8, 69-72.

Peters, J. M. (1967) Factors affecting caffeine toxicity: a review of the literature. F. New Drugs, 7, $131-141$.

StizXNski, B. M. (1971) Immediate effects of chemicals on mouse chromosomes. I. Caffeine. Curr. Mod. Biol. 3, 285-290.

Trmson, J. (1970) The effect of caffeine on the mitosis of human lymphocytes in cultures. Br. F. Pharmac. Chemother. 38, 731-734.

Ts'o, P. O. P. \& Lu, P. (1963) Physical binding of thymine, adenine, caffeine, steroids and phenanthrene to DNA and Poly A. Fedn Proc. Fedn Am. Socs exp. Biol. 22, 583.

WRAGG, J. B., CARR, J. V. \& Ross, V. (1967) Inhibition of DNA polymerase activity by caffeine in a mammalian cell line. J. Cell Biol. 35, 146a. 